\title{
Psykotiske pasienter har rett til behandling - frivillig og under tvungent psykisk helsevern
}

DEBATT

\section{VÅRIN HELLEVIK}

E-post: varin.hellevik@helsedir.no

Vårin Hellevik er advokat og seniorrådgiver i Avdeling helserett og bioteknologi i Helsedirektoratet.

Forfatteren har fylt ut ICMJE-skjemaet og oppgir ingen interessekonflikter.

\section{HANNE SKUI}

Hanne Skui er advokat og seniorrådgiver i Avdeling helserett og bioteknologi i Helsedirektoratet. Forfatteren har fylt ut ICMJE-skjemaet og oppgir ingen interessekonflikter.

\section{ANNE LOUISE VALLE}

Anne Louise Valle er avdelingsdirektør i Avdeling helserett og bioteknologi i Helsedirektoratet. Forfatteren har fylt ut ICMJE-skjemaet og oppgir ingen interessekonflikter.

Pasienter med «alvorlig sinnslidelse» uten samtykkekompetanse som er i behov av psykisk helsevern, skal ikke behandles på frivillig grunnlag. For mange behandlere virker det fremmed å treffe vedtak om tvang når pasienten ikke motsetter seg behandling.

Pål Gjerden peker på noen sider ved dagens regelverk som kan være utfordrende (1), men beskrivelsen hans krever noen oppklaringer og nyanseringer. Utgangspunktet for all helsehjelp, også hjelp i psykisk helsevern, er at pasienten skal samtykke til behandling. Samtykket forutsetter at pasienten er informert. Dessuten må pasienten forstå informasjonen om helsetilstanden sin og helsehjelpen som tilbys - altså ha samtykkekompetanse. Pasienter i psykotisk tilstand vil noen ganger mangle samtykkekompetanse, men ikke alltid. Spørsmålet er om vedkommende er i stand til å ta et valg som ikke i for stor grad er påvirket av sykdommen. Samtykkekompetansen må vurderes i konkret tilknytning til hvert enkelt behandlingstiltak.

Det har nok vært en misforståelse i psykisk helsevern at så lenge en pasient uten samtykkekompetanse ikke motsetter seg behandlingen, er behandlingen «frivillig». Dersom pasienten samtidig vurderes å ha en «alvorlig sinnslidelse», kan behandling imidlertid bare skje etter vedtak om tvungent psykisk helsevern, jf. pasient- og brukerrettighetsloven § 4-3 femte ledd, som henviser til psykisk helsevernloven kapittel 3.

I september 2017 ble det innført et krav om manglende samtykkekompetanse ved bruk av tvungent psykisk helsevern. Kravet «tvinger» frem vurdering av samtykkekompetanse. Dette har flere fordeler. For det første styrkes rettssikkerheten til en sårbar pasientgruppe som 
mangler samtykkekompetanse, ved at de får vedtak om tvungent vern med påfølgende klagerett og oppfølging av kontrollkommisjon. For det andre får nærmeste pårørende nå sine rettigheter til informasjon og medvirkning i større grad oppfylt, fordi deres rettigheter nettopp utløses når pasienten vurderes å mangle samtykkekompetanse (2).

Noen mener i likhet med Gjerden at kriteriene for vurdering av samtykkekompetanse er vage og gir stort rom for personlig skjønn. For å kvalitetssikre disse vurderingene har Helsedirektoratet utarbeidet et rundskriv med veiledning (3). I tillegg lager Senter for medisinsk etikk ved Universitetet i Oslo et opplæringsprogram (e-læring) for kompetansevurderinger. Programmet er planlagt ferdigstilt i første del av 2019, og vil sammen med rundskrivet være et nyttig verktøy for behandlere i kommune- og spesialisthelsetjenestene og for kontrollinstansene. Høyesterett har også nylig kommet med uttalelser knyttet til vurdering av samtykkekompetanse (4).

I tillegg til at vurdering av samtykkekompetanse tidvis oppleves vanskelig, er det særlig to følger av kravet om samtykkekompetanse som Gjerden og andre behandlere reagerer på. Den ene er at man må etablere tvungent psykisk helsevern for pasienter med «alvorlig sinnslidelse» som mangler samtykkekompetanse og som ikke motsetter seg behandlingen, slik vi har omtalt ovenfor. Denne regelen kan oppleves å være i strid med prinsippet om at frivillighet skal forsøkes, og en tilbakemelding fra helsepersonell er at noen pasienter og pårørende kan oppleve tvangsvern som mer krenkende enn betryggende.

Kanskje bør denne regelen i psykisk helsevern nyanseres og harmoniseres med somatikken? I somatikken er tvangsvedtak først aktuelt hvis pasienten som mangler samtykkekompetanse, motsetter seg helsehjelpen, jf. pasient- og brukerrettighetsloven kapittel 4A. Der det ikke foreligger motstand, kan ansvarlig helsepersonell beslutte helsehjelp, jf. pasient- og brukerrettighetsloven $\S 4-6$. Sistnevnte bestemmelse hjemler også behandling av psykisk lidelse som ikke er «alvorlig sinnslidelse», for eksempel til bruk på sykehjem. Representert samtykke ved «alvorlig sinnslidelse» er et av mange viktige spørsmål som Tvangslovutvalget ser på i disse dager. Utvalget vurderer tvangsreglene på helse- og omsorgsfeltet samlet, og vil avgi sin NOU-rapport i juni 2019.

For det andre er Gjerden ikke alene om å sette spørsmålstegn ved fremgangsmåten når en frivillig innlagt pasient mister samtykkekompetansen, og dermed skal konverteres til tvungent vern. Dersom en frivillig henvist pasient ikke har samtykkekompetanse ved innleggelse - eller mister den underveis - må det etableres tvungent vern dersom innleggelsen skal fortsette. Konverteringsforbudet innebærer at en frivillig innlagt pasient må få forlate institusjonen dersom vedkommende ønsker det, før tvungent vern etableres, jf. psykisk helsevernloven §3-4. Dersom pasienten ikke ønsker å forlate institusjonen, eller dersom farevilkåret vurderes oppfylt, kan tvungent vern etableres uten at pasienten først har forlatt institusjonen. Da må institusjonen tilkalle ekstern uavhengig lege som må vurdere om vilkårene for tvungent vern er oppfylt, jf. psykisk helsevernloven § 3-3 nr. 2 og § $3^{-1}$.

Hvis pasienten derimot benytter sin rett til å forlate institusjonen, kan det være faglig uforsvarlig ikke å ta initiativ til videre oppfølging. Pasienten er jo vurdert å mangle samtykkekompetanse og ofte sterkt behandlingstrengende. I slike tilfeller må behandler kontakte fastlege, psykisk helse i kommunen (FACT-team, fleksibel aktiv oppsøkende behandling) eller kommuneoverlegen med oppfordring om å oppsøke pasienten og bringe vedkommende til behandling, om nødvendig under tvungent vern. Dette bør gjøres per telefon for å sikre rask oppfølging.

Vi har fått tilbakemelding om at henvisende leger trenger mer opplæring $\mathrm{i}$ kompetansevurderinger. Noen pasienter som mangler samtykkekompetanse, blir henvist til frivillig innleggelse med de vansker som da oppstår knyttet til konverteringsforbudet. Kanskje er ikke henvisende leger tilstrekkelig oppmerksomme på at når pasienten mangler samtykkekompetanse, er frivillighet «åpenbart formålsløst å forsøke», jf. psykisk helsevernloven § 3-3 nr. 1. Henvisende leger oppfordres til å lese om 
kompetansevurderinger i nevnte rundskriv og benytte seg av e-opplæringsprogrammet når det er ferdig.

\section{LITTERATUR:}

1. Gjerden P. Psykotiske pasienter nektes behandling på frivillig grunnlag. Tidsskr Nor Legeforen 2019; 139. doi: 10.4045/tidsskr.18.0859. [CrossRef]

2. Fortolkning - Psykisk helsevernloven - Informasjon til pårørende. Helsedirektoratet.no. https://helsedirektoratet.no/Documents/Lovfortolkninger/Psykisk\%2ohelsevernloven/Fortolkning\%20 -\%2oPsykisk\%2ohelsevernloven\%2o-\%2oInformasjon\%2otil\%2op\%c3\%a5r\%c3\%b8rende.PDF (26.11.2018).

3. Psykisk helsevernloven og psykisk helsevernforskriften med kommentarer. IS-1/2017. Oslo: Helsedirektoratet, 2017: 12.

https://helsedirektoratet.no/retningslinjer/psykisk-helsevernloven-og-psykisk-helsevernforskriften-m ed-kommentarer (26.11.2018).

4. Dom Høyesterett 20.11.2018, HR-2018-2204-A.

www.lovdata.nohttps://lovdata.no/dokument/HRSIV/avgjorelse/hr-2018-2204-a?qHR-2018-2204-A (4.1.2019).

Publisert: 11. februar 2019. Tidsskr Nor Legeforen. DOI: 10.4045/tidsskr.18.0918

(C) Tidsskrift for Den norske legeforening 2020. Lastet ned fra tidsskriftet.no 